\title{
A NOTE ON ABBREVIATIONS
}

Unless otherwise noted, for Julian's works, I have followed the numbering system of Wright in the readily available Loeb series (1913-1923), although occasionally with slightly different titles. Abbreviations of other ancient sources follow Simon Hornblower and Antony Spawforth, eds., The Oxford Classical Dictionary, 4th ed. (Oxford: Oxford University Press, 2012); Henry George Liddell, Robert Scott, Henry Stuart Jones, and Roderick McKenzie, A Greek-English Lexicon, 9th ed. (Oxford: Clarendon Press, 1998); and G. W. H. Lampe, A Patristic Greek Lexicon (Oxford: Clarendon Press, 1961).

Table 1 Numbering and abbreviation of Julian's works

\begin{tabular}{ll}
\hline Wright (LCL) NUMbERING & BIDEZ ET AL. (LBL) NUMBERING \\
\hline & \\
Or. 1 Panegyric in Honor of Constantius & I \\
Or. 2, On Kingship & III \\
Or. 3, To the Empress Eusebia & II \\
Or. 4, Hymn to King Helios & XI \\
Or. 5, Hymn to the Mother of the Gods & VIII \\
Or. 6, Against the Uneducated Cynics & IX \\
Or. 7, To the Cynic Heracleios & VII \\
Or. 8, On the Departure of Salutius & IV \\
Letter to Themistius the Philosopher (Ep. Them.) & VI \\
Letter to the Senate and People of Athens (Ep. Ath.) & V \\
Fragment of a Letter to a Priest (Letter to a Priest) & Ep. $89 \mathrm{~b}$ \\
Symposium & X \\
Misopogon (Misop.) & XII \\
Against the Galilaeans or Contra Galilaeos (CG) & \\
Ep. 2, To Priscus & Ep. 12 \\
Ep. 4, To Oribasius & Ep. 14 \\
Ep. 8, To Maximus & Ep. 26 \\
Ep. 9, To His Uncle Julian & Ep. 28 \\
Ep. 14, To Prohaeresius & Ep. 31 \\
& \\
&
\end{tabular}

(continued) 
Table 1 (continued)

\begin{tabular}{ll} 
Wright (LCL) NUmbering & BideZ ET AL. (LBL) NUMBERING \\
\hline Ep. 15, To Aetius & Ep. 46 \\
Ep. 18, To an Official & Ep. 88 \\
Ep. 19, To a Priest & Ep. 79 \\
Ep. 20, To Theodorus & Ep. $89 \mathrm{a}$ \\
Ep. 21, To the Alexandrians & Ep. 60 \\
Ep. 22, To Arsacius & Ep. $84 \mathrm{a}$ \\
Ep. 23 To Ecdicius & Ep. 107 \\
Ep. 24, To the Alexandrians & Ep. 110 \\
Ep. 25, To Evagrius & Ep. 4 \\
Ep. 31, Edict on Physicians & Ep. $75 \mathrm{~b}$ \\
Ep. 33, To Theodora & Ep. 85 \\
Ep. 36, Edict on Christian Teachers & Ep. $61 \mathrm{c}$ \\
Ep. 37, To Atarbius & Ep. 83 \\
Ep. 38, To Porphyrius & Ep. 106 \\
Ep. 40, To Hecebolius & Ep. 115 \\
Ep. 41, To the Bostrenians & Ep. 114 \\
Ep. 45, To Ecdicius & Ep. 108 \\
Ep. 46, To Ecdicius & Ep. 112 \\
Ep. 47, To the Alexandrians & Ep. 111 \\
Ep. 49, To Ecdicius & Ep. 109 \\
Ep. 50, To Nilus & Ep. 82 \\
Ep. 51, To the Jews & Ep. 204 \\
Ep. 55, To Photinus & Ep. 90 \\
Ep. 56, Edict on Funerals & Ep. $136 \mathrm{~b}$ \\
fr. 11, From Lydus & Ep. 134 \\
\hline &
\end{tabular}


JULIAN AND CHRISTIANITY 
